Discussion Paper No. 00-35

\title{
Internationalisation of High-Tech Start-Ups and Fast Growth -Evidence for UK and Germany
}

Oliver Bürgel, Andreas Fier, Georg Licht, Gordon Murray 



\section{NON-TECHNICAL SUMMARY}

In recent years, much of the debate of policy makers, business academics and practitioners alike has centred on the nature and implications of the increasing importance of trans- and multi-national, economic activity. Globalisation, the phenomenon of increasing economic interdependence across national borders, is believed to be particularly pertinent to hightechnology industries. These sectors are commonly characterised by high costs for research and development, decreasing product and technology life cycles and strong competition from foreign firms. Strategies that large multinationals have followed to react to the 'forces' of globalisation have included, for example, international expansion to achieve economies of scale and simultaneous product launches in several countries in order to maximise international returns in dynamic markets subject to fierce and immediate competitor responses. Each of these strategies requires large managerial and financial resources. Therefore, the question arises as to how can high-tech start-ups, the smallest players in the high-technology sectors, cope with these challenges? Can these firms sustain resource-intensive entry modes in order to establish an international presence? Acting in technological niches, the expansion into foreign markets can be a way to increase sales and to thus to recover initial sunk costs over a shorter time frame.

Our research, based on survey data for British and German high-tech startups, examines whether internationalisation leads to faster growth among high-tech start-ups. Results show that firms with international sales have higher sales growth than firms that sell only domestically. We find that technological sophistication of products and the experience of entrepreneurs has a positive impact on growth. In addition, intense competition and shorter windows of opportunity increase the pressure to grow rapidly to appropriate the returns from innovation. The findings suggest that high tech firm founders should be more determinedly international in their vision and strategies from the very start of their business to increase the economic success of their efforts. 


\section{DAS WICHTIGSTE IN KÜRZE}

Die wachsende Bedeutung internationaler Aktivitäten hat in den vergangenen Jahren mehr und mehr Aufmerksamkeit gewonnen. Dabei scheint die Globalisierung als Phänomen steigender wirtschaftlicher Interdependenz für die High-Tech Industrie besonders relevant zu sein. Dies ist darauf zurückzuführen, daß sich der High-Tech Sektor durch hohe Forschungs- und Entwicklungskosten, verkürzte Produktlebenszyklen und ein enges internationales Wettbewerbsumfeld auszeichnet. Deshalb nutzen multinationale Unternehmen strategische Instrumente, indem sie zum Beispiel international expandieren, um Skalenerträge zu erhöhen, oder indem sie neue Produkte zeitgleich in mehreren Ländern einführen. Ziel ist es, Gewinne auf Märkten $\mathrm{zu}$ maximieren, in denen sie sich besonderen Wettbewerbsbedingungen ausgesetzt sehen. Da diese Strategien enorme finanzielle und organisatorische Ressourcen erfordern, stellt sich die Frage, wie die kleinsten Unternehmen im High-tech Sektor, die "High-tech Start-ups", sich solchen Herausforderungen stellen. Ist diesen Unternehmen ein ressourcen-intensiver Markteintritt möglich, um früh eine internationale Präsenz zu entwickeln? Eine mögliche Marktstrategie solcher Nischenanbieter kann die Expansion in Auslandsmärkte sein. Auf diese Weise lassen sich Absatzzahlen steigern und Anfangsinvestitionen schneller amortisieren.

Die vorliegende Studie bedient sich Umfragedaten britischer und deutscher High-tech Jungunternehmen und untersucht, inwieweit die Internationalisierung zu einem schnelleren Wachstum unter diesen "High-tech Start-ups" führen kann. Die Ergebnisse verdeutlichen, daß die Absatzzahlen in international aktiven Unternehmen stärker wachsen als bei Start-ups, die nur im Inland tätig sind. Es zeigt sich, daß technologisch differenzierte Produkte sowie die Erfahrungen des Unternehmensgründers positive Auswirkungen auf den Absatz haben. Weiterhin verstärken intensiver Wettbewerb und kürzere Zeitfenster den Druck, rapides Wachstum zu generieren, um die hohen Innovationskosten zu decken. Die Ergebnisse legen es nahe, daß zur Steigerung des wirtschaftlichen Erfolgs High-tech Unternehmensgründer so früh wie möglich eine Internationalisierung ihrer Strategien und Visionen beginnen sollten. 


\title{
Internationalisation of High-Tech Start-Ups and Fast Growth - Evidence for UK and Germany
}

\author{
by \\ Oliver Bürgel, Gordon Murray \\ London Business School \\ Andreas Fier, Georg Licht \\ Center for European Economic Research
}

\begin{abstract}
For firms acting in technological niches the expansion into foreign markets can be a way to increase sales and to thus to recover initial sunk costs over a shorter time frame. Our research, based on survey data for nearly 600 British and German high-tech start-ups, examines whether internationalisation leads to faster growth among high-tech start-ups. Results show that firms with international sales have higher sales growth than firms that sell only domestically. We find that technological sophistication of products and the experience of entrepreneurs has a positive impact on growth. In addition, intense competition and shorter windows of opportunity increase the pressure to grow rapidly to appropriate the returns from innovation. The findings suggest that high tech firm founders should be more determinedly international in their vision and strategies from the very start of their business to increase the economic success of their efforts.
\end{abstract}

Keywords: start-ups, high-technology industries, internationalisation

JEL Class: L 21, L 60, F 23

Acknowledgements: Financial support from the Anglo-German Foundation for the Study of Industrial Society, Apax Partners \& Co. Ventures Ltd. and the Department of Trade \& Industry (UK government) is gratefully acknowledged. The authors would also like to recognise the valuable contribution of Gregor Frieb and Juliane Lauer in preparing the data for the analysis and for the final reading. All errors of fact and/or omission remain solely to the responsibility of the named authors. 


\section{Introduction}

Much attention in the empirical entrepreneurship research is devoted to the growth and survival of young enterprises. Arguably this is due to the large potential for job creation by new businesses. In nearly all European countries, economic policy makers increasingly attempt to improve the climate for the genesis and growth of new businesses. Often these policies are targeted to high-tech enterprises. These attempts receive support by recent research results (e.g. Almus, Nerlinger \& Steil, 1999) showing that growth and survival rates of start-ups in high-tech sectors are significantly larger than in other sectors of the economy. More recently, the rapid internationalisation of high-tech start-ups generated an increasing amount of attention by entrepreneurship scholars. It is argued that global markets presence is essential for a firm's success and the ability to reap the profits from innovation. Case study evidence suggests that early internationalisation is a contributor to success in high-tech markets. The step from home to foreign markets is often associated with large growth prospects. 70\% (60\%) of UK (German) firms in our sample of high-tech start-ups consider the potential of foreign markets for long-term company growth as their main motive for international business activities. Given shorter product life cycles in high-tech markets the expansion of the potential market for their products or services seems especially important for young firms acting in technological niches. They often have to recover considerable initial R\&D expenses or other investments in human or capital assets in a short period of time. Invariably, international business activities are more costly and time consuming for a small firm than serving just a local or national home market. As a result rapid internationalisation firms can also retard firm growth. Therefore, the growth enhancing effects of international business activities may be seen as ambiguous - at least in the short run.

In this study we try to examine this question in more detail. By looking at high-tech start-ups in two European countries we also try to shed some light on the importance of firm-specific factors, 'regional' endowment and rapid internationalisation of sales on the performance of start-ups in early stages of their life cycle. Depending on characteristics of the firm, their founders and their products we have already shown in related papers that early international expansion is an important feature of many high-tech start-ups (e.g. Burgel et al., 1999). The paper is structured as follows: The next section shortly summarises the existing research on international sales, innovation and performance at the firm level. We then describe the data set 
used and the theoretical foundations for our empirical model. After that, we present our empirical results and look at the growth performance of hightech start-ups with and without international sales in their early years. Finally, we summarises our main result and draws some conclusions.

\section{Review of the Recent Literature}

In the field of industrial economics, a number of authors have looked at the export probabilities of plants and the relation of international sales on firm performance. Roberts and Tybout (1997) stress that sunk cost of market entry are important in explaining the export decision. Employing a dynamic discrete-choice model, they show that sunk entry cost and past export experience are important determinants of current export status of the plants in their sample. Using US data, Bernard and Jensen (1999) show that 'above average quality' firms become exporters. However, the direction of causality is important and being an exporter does not affect the 'quality' of a firm. In addition, Bernard and Jensen show that the export status has a positive impact on the growth of surviving firms. Similar results are presented by Bernard and Wagner (1997) for Germany. Moreover, the evidence presented in Clerides, Lach und Tybout (1998) is also not consistent with the 'learning-by-exporting' hypothesis. They show that a self-selection process of the better firms deciding to enter the export market is responsible for the better performance of exporters. In addition, Wakelin (1998) shows that past innovations positively effect the export probability of large UK firms. Ebling and Janz (1998) look at the propensity to export and innovation in the service sector. They show that it is more likely that innovation causes the export status than vice a versa.

However, the above empirical evidence has been obtained from studies of well established medium sized and large firms. Start-up companies in hightechnology market may exhibit materially different characteristics. More specific literature dealing with the performance and internationalisation of young high-technology firms is available in the entrepreneurship literature. McDougall and Oviatt (1996) show that increased international exposure only enhances firm performance when international market entry is accompanied by a change in firm's strategy. Bloodgood, Almeida and Sapienza (1996) looked at a sample of high-tech ventures at the time of their IPO and two years later. They found that internationalisation was positively related to the absolute level of sales but not to sales growth. They explain the latter finding with the fact that the more international firms were already the 
largest at the time of IPO. Lindqvist (1991), McDougall, Shane and Oviatt (1994), Bell (1995), as well as Reuber and Fischer (1997) point towards the effects of specific technological advantages and international work experience of the founders on the likelihood of international sales in early stages of the firms life cycle. Thus, only McDougall and Oviatt and Bloodgood et al. made first steps to specifically examine the performance of their internationalising start-ups. Yet, their findings on whether internationalisation enhances start-up performance remain somewhat inconclusive. Furthermore, to our knowledge, no study has tried to investigate this issue with a non-US dataset looking at a random sample of firms.

\section{Theoretical Framework}

The basic idea behind our approach are the standard empirical growth models well-known from the literature on firm growth (see the recent surveys by Sutton, 1998 and Caves, 1998) and to augment these models by employing specific variables relevant to our analysis of international sales. We will not only look at the average growth rate of the firm but also examine more closely whether or not internationalisation increased the share of fast growing firms (often called gazelles). It is these 'fast tracker' firms (Storey, 1994) which are the most important enterprises when looking at the macroeconomic effects of start-ups. The standard econometric growth model which is used in dozens of papers to test Gibrat's Law can be written as

$$
\ln \left(\frac{A_{t+1}}{A_{t}}\right)=\sum_{i=0}^{n} \beta_{i} \cdot \ln \left(\mu_{i}\right)+(\theta-1) \cdot \ln \left(A_{t}\right)+\varepsilon
$$

whereby $\mathrm{A}$ is the performance measure of interest (sales, employment) and $\mathrm{t}$ and $t+1$ indicate time periods. $\mu$ can be thought of as a measure for, or a proxy of, a particular factor effecting the average growth rate of the i-th group of firms (e.g. features of an certain industry). $\beta$ indicates whether those features are associated with above or below average growth rates. Davis, Haltiwanger \& Schuh (1996) argue that firm growth is largely driven by idiosyncratic features (e.g. management strategies) and that standard economic variables (like industry, size, foreign competition) rather imperfectly explain firm growth.. Our data allow us to uncover some of those idiosyncrasies like human capital endowment of the firm, product and owner characteristics. Gibrat's Law proposes that $\theta-1$ is 0 and $\varepsilon$ is a normally distributed, random effect. Stated otherwise, Gibrat's law simply 
says that the size of firms is dependent on a series of random shocks, and the size distribution within a more or less homogenous group of firms is $\log$ normal. As it is obvious from Figure 1, the distributions of the logarithm of sales and employment of our sample come rather close to a normal. However, the existing empirical literature (see Caves, 1998) stresses that Gibrat's Law does not hold for young and small firms and that there are negative impacts of size on firm growth. Therefore, we should expect that $\theta$ is smaller than 1 so that the rate of growth decreases with firm size. In addition, the literature unequivocally points towards a negative effect of firm maturity on growth: simply put - old firms grow less. As both size and age dependency are fairly established in the economic literature (see Sutton, 1998, for a review), we viewed a replication of these common results as corroborating the model specification chosen.

We hypothesise that additional factors affect the average growth rate and be included as part of the vector $\mu$ equation (1). In line with empircal findings from the international entrepreneurship literature (Bloodgood, Almeida and Sapienza 1996; McDougall, Shane and Oviatt, 1994; Lindqvist 1991; Reuber and Fischer 1997), we expect a positive impact on young firm growth from early internationalisation, larger human capital of founders, larger technological sophistication of the product and a low degree of diversification. Most importantly, international sales are expected to foster firm growth.

\section{Data Collection and Sampling}

One important aim of this study is to analyse the internationalisation of startups with a relatively large sample of firms utilising a comparable basis of selection in both Germany and the UK. Arguably, our results are more reliable when we use data of firms with different national backgrounds. Given the existing differences in the trade patterns of the UK and Germany as well as differences in their technological infrastructures and educational systems, combining data from both countries will offer the opportunity to partial out the effects which are probably correlated with firm's behaviour towards international high-tech markets.

\subsection{The Questionnaire}

Data for the study was generated through a mail survey using a four page questionnaire which was identical in both countries. The questionnaire 
included variables to measure 'transaction costs' during the sales process and proxies for situation in which high transaction are expected to occur. In addition, information on the commercial and international experience of founders was requested. We also asked respondents several general questions about the characteristics of their firm, including details of the traded products and services as well as the resources devoted to R\&D. Finally, the respondents were asked to rank different motivations for international activities, and to determine the scale of costs and constraints which they had experienced during this process.

\subsection{Definition of High-tech Start-ups (NTBFs)}

For the purpose of this study, a high-tech start-up is defined as being a legally independent company which is no older than ten years and which operates in one or more high-technology sectors. We use the list of hightechnology sectors established by Butchart (1987) to determine the relevant sectors in manufacturing. In addition, we include start-ups from selected service industries which where found to be $R \& D$ intensive in a recent study for Germany (Licht et al., 1997). One major drawback of our study is that we neglect high-start ups in low-tech industries. Yet, as opposed to targeting low-technology sectors in the search for high-technology start-ups, the proposed approach results in an increased likelihood of obtaining responses from firms that fulfil the specified sampling criteria for our mail survey. Details on the included industries are given in the appendix.

\subsection{Data Sources and Sampling Frame}

We use sampling frames resulting from similar data sources in both countries. Sampling was based on a databases for firms operating in the industries defined above, which had at least three employees in 1997, and that had been founded between 1987 and 1996. To identify those firms we used Dun \& Bradstreet in the UK and Creditreform in Germany which are the leading credit rating and business information agencies in both countries. All identified company records were subsequently screened to exclude those firms whose business activities suggested that they are not primarily engaged in producing and developing new products, services or processes. As a result, 2,671 firms in UK respectively 5045 firms in Germany were retained as eligible for inclusion in the res earch sample. In each country we select 2,000 firms for inclusion in the survey using a stratified random sampling process (i.e. stratified by size class and service/manufacturing categorisation). 


\subsection{The Survey}

The mail survey was started in October 1997. It resulted in 232 usable questionnaire for Germany and 362 for the UK. While there is a difference of response rates between the countries ( $24 \%$ of eligible firms in the UK; $14 \%$ in Germany), the response rates within the strata were distributed in a quite similar way which hints at a low selectivity bias in the response behaviour of firms. In order to calculate the weights for each strata, two different factors, the drawing probability and the response probability, were taken into account. The drawing probability accounts for the bias introduced through the deliberate over- or under-sampling due to the stratified random sampling. It is calculated by dividing the number of firms by the number of firms in the adjusted (cleaned) Dun \& Bradstreet respectively Creditreform sample per strata. As we are interested in inferring from our sample on the total population of firms, we also adjusted these drawing probabilities with the response probability per strata. Therefore, strata specific weights are calculated as the inverse of the product of drawing probability and response probability.

\section{Descriptive Analysis}

The mean and the standard deviation for the variables use in this study are summarised in Table 1. The most important message of this table is that the firms from both countries appear rather similar. Obvious differences between the UK and Germany exist mainly with regard to the age of the firm which is simply due to the fact that East-German firms are not present for start-ups year 1987-90. The majority of high-tech start-ups enter international markets in the first decade of their existence. Even when we consider that the share of internationally active firms could be subject to overestimation due to a response bias, we nevertheless are quite surprised by the large share of internationalised start-ups. The similarity between both samples is confirmed when looking at mean values. Both the German and the UK sample show similar characteristics with regard to various key variables, i.e. the distribution of firm size is rather similar in the UK and in Germany at time of start-up and also at the time of the survey.

These similarities are confirmed by looking beyond those descriptive summary statistics. Figure 1 shows weighted, non parametric, kernel density estimates (a non-parametric estimation technique to analyse distributions) for sales and employment growth. At first sight, we can conclude that the 
logarithm of the differences in sales as well in employment levels is approximately normally distributed. Moreover, the distribution of growth rates seems not to differ much between Germany and the UK. Most of the (surviving) firms in both countries showed an impressive sales growth rate of between 25 and 35 per cent a year. Employment growth is broadly similar except that growth rates were somewhat slower with the majority of firms falling into the 17 to 25 per cent interval. We now investigate to what extent internationalisation affects the growth rate of our firms.

\section{Results and Discussion}

\subsection{Definition of Growth}

We examined the average growth experienced by the firms in the sample between (a) the (expected) sales in the current financial year and the first financial year in which the firms generated sales, and (b) the employment at the time of the survey and the employment at start-up. Because of different ages of the firms in our sample, growth is best measured using the 'average yearly growth rates' (see Evans, 1987):

$$
G_{i}=\frac{\ln A_{t_{i 2}}-\ln A_{t_{i 1}}}{\left(t_{i 2}-t_{i 1}\right)}
$$

The growth rate of the variable A (sales, employment) between two time intervals $t_{2}$ and $t_{1}$ is calculated as the difference at this two points in time of the employment levels after taking logs, and then divided the difference by the length of the interval. This formulation implicitly assumes an exponential growth path which is a fairly standard economic assumption.

\subsection{Estimation procedures}

Inference about the determinants of firm growth might be biased if there is some element of endogeneity among the independent variables. For example, if venture capitalists selected their investee firms based on previous track record, the causal relationship would run from (past) growth to venture capital involvement and not the other way round. The same argument can be used for internationalisation which can be expected to be endogenous because strong (past) growth will more probably bring a firm to the limits of the domestic market. The consequence of this saturated home market will be that the growing firms is obliged to internationalise. Thus, internationalisation becomes an outcome of growth and not vice versa. In 
order to avoid those problems, we will not use observed venture capital involvement nor observed internationalisation status but will use the predictions of the latent variables from probit models on venture capital involvement, internationalisation status and public grants availability as instruments for the underlying observation. (Estimation results for these equations are available from the authors upon request). Two approaches are used to assess the impact of internationalisation on growth. First, we estimate model given in (1) by an instrumental variable procedure. Second, we transform the growth rate into a dummy variable in order to look only at the differences between slow growing and fast growing firms. In addition, both models are estimated for sales as well as for employment growth. Given that sales and employment growth rates should be related, we expect similar impacts on other factors which influence sales and employment growth.

\subsection{Determinants of Firm growth}

The results of our regression models are presented in Table 2 and Table 3. Table 2 holds the results for the sales and employment growth models using standard OLS model with instruments for the internationalisation, venture capital and public grants status. Table 3 contain the probit model. Results for sales and employment growth are rather similar. Therefore, we will discuss results for both the sales and the employment growth model at once. We will highlight similarities and differences between both performance measures and interpret these findings in the line of the theoretical underpinnings and the existing literature.

International Sales: Firms with international sales showed larger growth rates than firm which only operate in the domestic market. The elasticity of the growth rate with respect to internationalisation amounted to $13 \%$. An $100 \%$ increase in the latent inclination to internationalisation would therefore imply an ncrease in the average growth rate from a $25 \%$ per year to $38 \%$ per year. Thus, the effect of internationalisation on sales growth was quite remarkable in its size. However, internationalisation only marginally affected employment growth. The results from the employment growth regression were statistically not different from zero. Taken together, the effect of internationalisation on sales growth and on employment growth confirmed the productivity enhancing effect of internationalisation as already indicated above. The growth motive of the owners or managers was confirmed by the observed growth rate differential between firms with 
international sales and firms without international sales. Therefore, internationalisation increased the returns to the initial investment in R\&D and human capital assets, both of which are necessary to enter high tech markets. The missing effect of internationalisation on employment growth should not viewed as indicating a business failure. Rather, given the large risk exposure of an high tech entrepreneur, the wealth creating effect of internationalisation likely remains a more important personal goal than the public externality of a short run, positive employment balance. It was also clear from an inspection of the distribution of growth rates that a large share of the additional sales and employment generation is due to a small number of firms. This seems to be especially true for the UK. Therefore, it is important to known whether or not the process of internationalisation contributed to the formation of these high growth/high potential firms. However, table 3 shows that international sales is, not an important stimuli for fast growth.

Country-specific effects: German start-ups showed a lower sales growth rate than UK start-ups in the 1990s period. However, this sales growth differential was mainly due to the lower performance of West-German companies which recorded on average a 6 per cent lower average yearly growth rate than for the UK firms. This clearly shows the influence of the macroeconomic slump which hit West-Germany during the 1990s. In addition, based on case study evidence for a small number of our sample firm, it is also possible that a shorter pre-formation period induce smaller sales in the first financial year for the UK firms implying a larger potential for growth in the following years.

Start-up size: All models demonstrated a strong negative effect for the initial firm size on firm growth. This is compatible with the hypothesis that there is a minimum efficient scale and that firms are regularly founded at a suboptimal size (see Ericson \& Pakes, 1995, Jovanovic, 1992). This result is also in line with the majority of the existing economic literature on start-up growth (see Wagner, 1992 for Germany, Dunne \& Hughes, 1994 for UK, Acs \& Audretsch, 1990 for the US). A competing interpretation of this relationship between firm size and growth was recently put forward by Chabral (1995). He argued that the larger growth rates of smaller firms results from under-investment due to uncertainty and the short-termism of start-ups. Therefore, the smaller the start-up size, the more surviving firms will reverse initial expectation on the subsequent evidence of growth. The 
firm will gain confidence which will in turn stimulate investment and further growth.

Age: Our regression results show a strong negative effect for age on firm growth. If Chabral's above hypothesis is true, we should not find a strong negative effect of age on growth. Therefore, we find the Ericson \& Pakes' alternative argument that firms learn about their productivity after market entry a more convincing story.

Size of Founding Team and Shortages of Skills: Initial constraints on human capital as well as financing constraints are probably less severe if the firm is founded by a team and not by a single owner. We should, therefore, expect lower growth rates for team start-ups than of single owner start-ups when looking at surviving firms since their start-up size is higher. However, especially in the first years of a firm's existence, a larger human capital base can also be view as a source of knowledge which can be turned to growth (see Bruederl, Preisendoerfer \& Ziegler, 1996). Conversely, it can also be argued that there is an increased chance that managers in a team will more likely be in conflict with each other resulting in growth reducing frictions (Eisenhardt \& Schoonhoven, 1990). However, our data was quite convincing: the larger the start-up team of owners/founders, the greater are the growth prospects of the firm. Venture capitalists' preference for teambased start-ups inves tments appears vindicated. In addition, we used the selfassessment of the present management to ascertain whether their company experienced severe skill shortages at the time of start-up. ${ }^{2}$ Our result do not point towards a significant effect of shortages in the marketing area on firm growth since we identified only a small negative impact on growth rates. In the light of the Ericson \& Pakes' framework, this would imply that knowhow shortages in technological fields have a stronger impact on initial size than shortages in the marketing field. The latter appeared to be more easily overcome in the first years.

Research \& Development: Sustaining investments in new technologies and new technological know-how is of major concern to high-technology firms. Our estimation results confirmed the large positive effects of R\&D on sales growth. The estimated coefficient implies a 5-6 \% larger sales growth compared to both non R\&D firms or firms which only occasionally conduct $R \& D$. However, the effect of $R \& D$ on employment growth is not significantly larger than zero. 
Window of Opportunity: Gaining profit from $\mathrm{R} \& \mathrm{D}$, or from other forms of investment in new technologies, is best made when the firm can generate a unique selling proposition. We tried to establish product uniqueness by using the time period which is necessary to enable a competitor to market a product with similar characteristics as the target product of the firm and at a competitive price. This competition-free time period is called the "window of opportunity'. We differentiated between firms which had an competitive advantage which was expected to last longer or less than one year. A fairly large number of firms were not able to give reliable estimates of their 'window of opportunity'. Those firms are treated as a separate group. Firms which had a rather short window of opportunity exhibited larger sales and employment growth rates. An obvious explanation is that those firms must exploit their competitive advantage quickly in order to generate a rapid growth path (Aghion \& Howitt 1994). If these firms experience delays, their technology-based competitive advantage will be quickly become eroded. In addition, firms with a longer window of opportunity appear to be especially cautions regarding their employment expansion. They seek to realise productivity gains with existing staff resources while exploiting their product based competitive edge. This can be seen as a risk reducing response given that the duration of a product/market advantage cannot be guaranteed in an uncertain environment. The result that longer windows of opportunity are positively associated with a smaller firm growth is in line with Porter's argument (see e.g. Porter 1979) that firms successfully occupying narrow strategic segments do not need to grow rapidly in order to survive in their chosen market.

Age of the Product: In rapidly changing markets, the age of the product may be more important for the firm's growth than the age of the firm itself. When we view high technology markets as markets in a formative stage of evolution, the importance of the establishment of a 'dominant design' becomes evident (see Klepper 1996). Short product life cycles are increasingly typical for high tech industries (see, for example, the rapid change, and obsolescence, in the design and functionality of mobile telephones or digital data storage devices). In these industries, older products do not signal tried-and-tested quality but, on the contrary, out-of-date and superseded designs. Therefore, we would expect higher growth rates in companies whose major products are relative immature. This expectations were confirmed by our estimates. The expansion of sales declines as the product gets older. However, this result appeared to be sensitive to, and influenced by, some 'outlier' firms which were active in the type of volatile 
technology markets describe above (table 3). For the more typical median firm, no such negative impact of product age on sales growth is obvious (table 2). In addition, the age of the product did not turn out to be significant in the employment growth regressions.

Product Diversification: Product differentiation was measured by the sales share of the best selling product. The smaller this share is, the more a firm can be described as highly diversified. The results of our models suggest that specialisation has a sales growth enhancing effect. The larger the share of the best selling product, the larger was the observed sales growth rate of the whole firm. So, product diversification is probably not a strategy that pays in early years. This is a plausible finding given that both production and marketing activities in complex technologies benefit from specialisation. Diversifying across either technologies or product markets is likely to result in a sub-optimal use of scarce resources for the smaller firm. This characteristic of the product spectrum of a firm seems no to have any implication for employment growth. Therefore, this variable was dropped from the final version of the employment growth regression model.

Financing of Start-up by Venture Capital and Public Grants: Although the political focus of discussions on financing start-ups is primarily directed to the question of how to generate more start-ups, some researchers also have argued that the financing issue is also relevant for the growth process in young and small companies (e.g. Cressy, 1996). However, empirical results on the presence of financing constraints on the firm growth are less well researched. Case study evidence also appears to support these expectations of venture capital's positive effect on the growth of start-ups (see Oakey et al., 1988; Murray, 1995). The empirical modelling started from the hypothesis that venture capital and public grants either relax the financing constraints or lower financing costs to the start-up or young firm. VCbacked firms can move rapidly down their 'marginal cost of expansion' function (see the model in Carpenter \& Peterson, 1998). The result is seen in higher growth rates for these firms. Perversely, the evidence we generated from the model did not support the existence of financing constraints. Neither venture capital backing nor the presence of public grants enhanced the sales growth of recipient firms. Similarly, and continuing the pattern of earlier models, we did not find an employment growth effect from venture capital or public grants involvement. 


\section{Conclusions}

Nearly all firms in our sample showed an impressive track record of growth over their first years from formation. However, we should remember that due to our sampling procedure only firms surviving their first years are included. Thus, a survival bias exists in our survey samples both in Germany and the UK. This implies that the average growth rate of a complete cohort of new business is certainly lower that the average growth rate of our sample firms. Despite this caveat, it is well-known from other studies that high-tech start-ups show a higher survival rate - at least in their early years - than other firms (Agarwal, 1998). If non-surviving firms were also included in the data set, the differences between high-tech firms and non-high tech firms would be even more impressive. We found that internationally active firms have better sales performances than non-internationally active firms. Again, some caution is necessary when generalising this effect. As international business activities are probably more risky than purely domestic business activities, it may well be the case that the survivor bias lead to an overestimation of the positive wealth effect generated by early internationalisation of young hightech firms. This caveat calls for a careful study of the relationship between internationalisation and firm survival. This caution is particularly salient given the high expectation many politicians and scholars hold regarding the employment generating effect of start-ups. Our result indicate that early internationalisation does not necessarily also imply higher employment growth. Early internationalisation seemed to have positive effects on sales growth and competitiveness in the first place but not on employment. Finally, while internationalisation may often come by chance, our findings suggest that including the option to internationalise in the business plan enhances subsequent success in foreign markets. This important finding suggests that high tech firm founders should be more determinedly international in their vision and strategies from the very start of their planning if they wish to increase the economic success of their entrepreneurial efforts

\footnotetext{
Notes

${ }^{1}$ ) Using a factor analyses on various different types of possible management shortages (marketing, distribution, general management, financial management, production, R\&D) we isolated two types of shortages from the data: shortages in technological know-how (e.g. production or R\&D) and shortages in market related know-how (e.g. distribution channels, marketing).We use a 5-point Likert scale to evaluate whether a firm experienced a shortage of skill at the time of start-up where $1=$ "Not at all" and $5=$ "Strongly." The larger the resulting score, the larger the importance of skill shortages.
} 


\section{Appendix}

\section{Definition of High-Tech Industries}

\begin{tabular}{|c|c|c|}
\hline $\begin{array}{l}\text { Aggregated } \\
\text { industries used }\end{array}$ & NACE Rev. 1 & Short description according to NACE Rev.1 \\
\hline $\begin{array}{l}\text { R\&D intensive } \\
\text { service industries }\end{array}$ & $\begin{array}{l}64.20 ; 72.20 \\
72.30 ; 72.40 \\
72.60 ; 73.10\end{array}$ & $\begin{array}{l}\text { Telecommunication, Computer Programming and Software Services, } \\
\text { Data Processing, Misc. Computer Services, R\&D in Natural Sciences } \\
\text { and Engineering }\end{array}$ \\
\hline ICT-Hardware & $\begin{array}{l}30.01 ; 30.02 \\
32.20 ; 32.30\end{array}$ & $\begin{array}{l}\text { Office Equipment; Computers and other Information Processing } \\
\text { Equipment; Television and Radio Transmitters and Apparatus for Line } \\
\text { Telephony and Line Telegraphy; Television and Radio Receivers, } \\
\text { Sound or Video Recording and Reproducing Apparatus }\end{array}$ \\
\hline $\begin{array}{l}\text { Engineering } \\
\text { Industries }\end{array}$ & $\begin{array}{l}33.20 ; 33.30 \\
33.40\end{array}$ & $\begin{array}{l}\text { Electronic Instruments and Appliances for Measuring, Checking } \\
\text { (except Industrial Process Control); Electronic Industrial Process } \\
\text { Control Equipment; Optical Instruments; Photographic Equipment }\end{array}$ \\
\hline $\begin{array}{l}\text { Health and Life } \\
\text { Sciences }\end{array}$ & $\begin{array}{l}24.41 ; 24.42 ; \\
33.10\end{array}$ & $\begin{array}{l}\text { Pharmaceutical Products and Preparations; Medical and Surgical } \\
\text { Equipment and Orthopaedic Appliances }\end{array}$ \\
\hline $\begin{array}{l}\text { Misc. High-Tech } \\
\text { manufacturing }\end{array}$ & $\begin{array}{l}24.16 ; 24.17 \\
31.10 ; 31.20 \\
32.10 ; 35.30\end{array}$ & $\begin{array}{l}\text { Plastics and Synthetic Rubber in Primary Form; Electric Motors, } \\
\text { Generators and Transformers; Electricity Distribution and Control } \\
\text { Apparatus; Electronic Valves, Tubes and other Components; Aircraft } \\
\text { and Speedcraft Manufacturing }\end{array}$ \\
\hline
\end{tabular}

Figure 1: Estimated distribution of sales and employment growth of high-tech startups by country
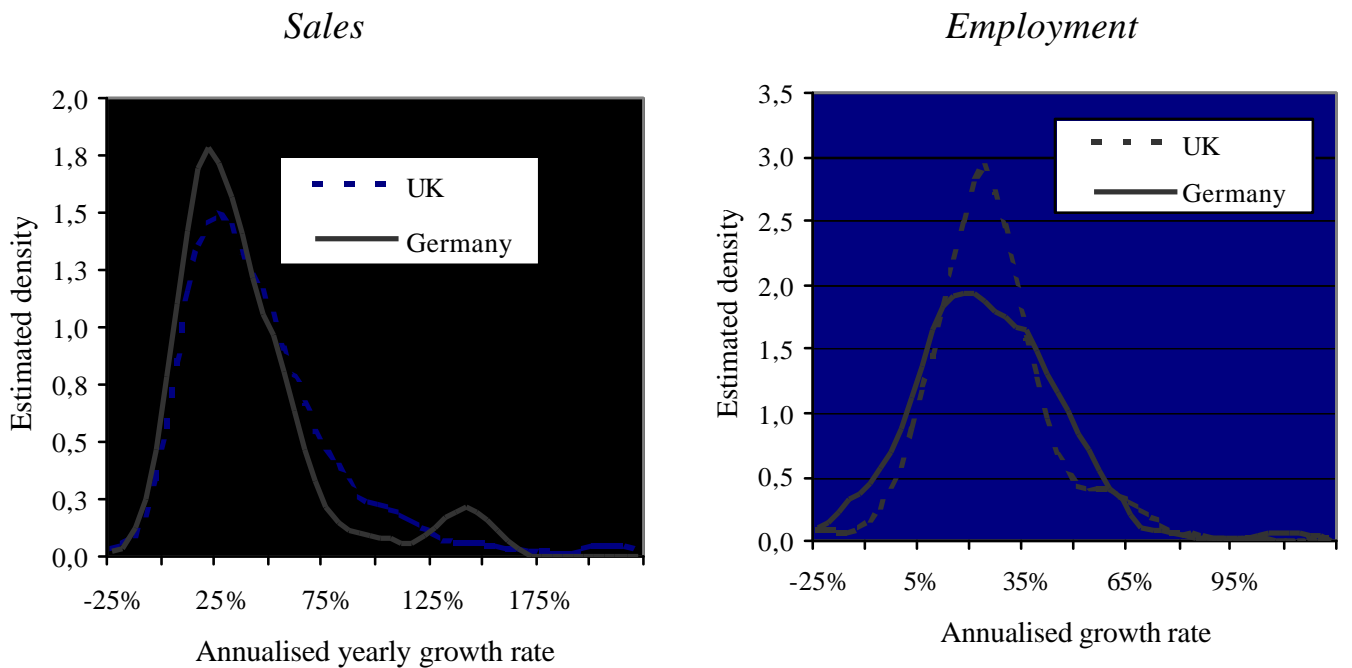

Source: LBS/ZEW (2000) 
Table 1: Descriptive Statistics for the UK and the German Data Set

\begin{tabular}{|c|c|c|c|c|c|c|c|c|}
\hline \multirow[b]{3}{*}{ Variable } & \multicolumn{4}{|c|}{ Raw Data } & \multicolumn{4}{|c|}{ Weighted data } \\
\hline & \multicolumn{2}{|c|}{ UK } & \multicolumn{2}{|c|}{ Germany } & \multicolumn{2}{|c|}{ UK } & \multicolumn{2}{|c|}{ Germany } \\
\hline & $\begin{array}{c}\text { Mean/ } \\
\text { Share }\end{array}$ & $\begin{array}{l}\text { Std. } \\
\text { Dev. }\end{array}$ & $\begin{array}{l}\text { Mean/ } \\
\text { Share }\end{array}$ & $\begin{array}{l}\text { Std. } \\
\text { Dev. }\end{array}$ & $\begin{array}{l}\text { Mean/ } \\
\text { Share }\end{array}$ & $\begin{array}{l}\text { Std. } \\
\text { Dev. }\end{array}$ & $\begin{array}{l}\text { Mean/ } \\
\text { Share }\end{array}$ & $\begin{array}{l}\text { Std. } \\
\text { Dev. }\end{array}$ \\
\hline West German Firm & & & 0,66 & & & & 0,75 & \\
\hline East German Firm & & & 0,34 & & & & 0,25 & \\
\hline ICT-Hardware & 0,21 & & 0,18 & & 0,18 & & 0,11 & \\
\hline Engineering & 0,17 & & 0,13 & & 0,14 & & 0,07 & \\
\hline Bio/Med/Life & 0,09 & & 0,08 & & 0,07 & & 0,05 & \\
\hline Other Industries & 0,26 & & 0,31 & & 0,22 & & 0,18 & \\
\hline International Sales & 0,71 & & 0,63 & & 0,63 & & 0,56 & \\
\hline Employment at start-up & 4,47 & 6,72 & 5,88 & 8,39 & 3,98 & 5,89 & 4,65 & 6,13 \\
\hline Employment 1998 & 20,17 & 23,70 & 18,85 & 21,17 & 16,30 & 21,38 & 15,22 & 18,40 \\
\hline Age of the Firm (1999) & 7,08 & 2,42 & 6,49 & 2,21 & 6,80 & 2,44 & 6,08 & 2,19 \\
\hline Venture Capital Backed & 0,11 & & 0,09 & & 0,10 & & 0,09 & \\
\hline Public Grants Recipient & 0,18 & & 0,27 & & 0,14 & & 0,20 & \\
\hline Work experience abroad & 0,53 & & 0,31 & & 0,52 & & 0,31 & \\
\hline Work experience in MNU & 0,51 & & 0,35 & & 0,48 & & 0,35 & \\
\hline Education abroad & 0,13 & & 0,15 & & 0,13 & & 0,15 & \\
\hline \multicolumn{9}{|l|}{ Number of Founders: } \\
\hline$-2-3$ & 0,43 & & 0,28 & & 0,44 & & 0,29 & \\
\hline$-3-4$ & 0,20 & & 0,31 & & 0,18 & & 0,29 & \\
\hline-5 and more & 0,05 & & 0,07 & & 0,06 & & 0,08 & \\
\hline R\&D employment share (in \%) & 20,86 & 19,74 & 19,62 & 20,15 & 22,78 & 21,62 & 23,03 & 22,61 \\
\hline R\&D performed occasionally & 0,27 & & 0,31 & & 0,31 & & 0,36 & \\
\hline R\&D performed permanently & 0,60 & & 0,49 & & 0,56 & & 0,41 & \\
\hline \multicolumn{9}{|l|}{ Window of Opportunity } \\
\hline Larger than 1 year & 0,53 & & 0,59 & & 0,53 & & 0,60 & \\
\hline Unknown & 0,23 & & 0,23 & & 0,22 & & 0,26 & \\
\hline High Degree of Customisation & 0,30 & & 0,35 & & 0,32 & & 0,30 & \\
\hline Age of Product & 5,36 & 2,52 & 5,34 & 2,21 & 5,18 & 2,51 & 5,05 & 2,22 \\
\hline $\begin{array}{l}\text { Share of Best Selling Products: } \\
-30-60 \%\end{array}$ & 0,37 & & 0,38 & & 0,36 & & 0,36 & \\
\hline$-60-80 \%$ & 0,30 & & 0,32 & & 0,32 & & 0,38 & \\
\hline$-80-100 \%$ & 0,12 & & 0,13 & & 0,13 & & 0,13 & \\
\hline Capital good & 0,35 & & 0,51 & & 0,34 & & 0,51 & \\
\hline Intermediate good / service & 0,33 & & 0,20 & & 0,31 & & 0,16 & \\
\hline
\end{tabular}

Source: LBS/ZEW (1999) 
Table 2: Sales and Employment Growth Regressions - Instrumental Variable Estimates

\begin{tabular}{|c|c|c|c|c|}
\hline \multirow[b]{2}{*}{ Exogenous variables } & \multicolumn{2}{|c|}{ Sales Growth } & \multicolumn{2}{|c|}{ Employment Growth } \\
\hline & Coeff. & Asy. t-value* & Coeff. & Asy. t-value* \\
\hline West-Germany & -0.061 & -1.98 & -0.020 & -1.09 \\
\hline East-Germany & 0.037 & 0.68 & -0.011 & -0.43 \\
\hline $\log ($ Age $)$ & -0.406 & -6.30 & -0.229 & -6.40 \\
\hline $\log ($ Sales first financial year $)$ & -0.132 & -7.55 & -0.121 & -12.46 \\
\hline $\begin{array}{l}\text { Number of Founders: } \\
2-3\end{array}$ & 0.045 & 1.55 & 0.009 & 0.53 \\
\hline $3-4$ & 0.120 & 2.93 & 0.036 & 1.90 \\
\hline 5 and more & 0.190 & 2.29 & 0.031 & 0.90 \\
\hline $\begin{array}{l}\text { Shortage in competencies: } \\
\text { Sale/Marketing }\end{array}$ & 0.010 & 0.67 & -0.001 & -0.08 \\
\hline Production/R\&D & 0.018 & 1.05 & 0.014 & 1.36 \\
\hline Permanent R\&D & 0.064 & 2.35 & 0.022 & 1.43 \\
\hline $\begin{array}{l}\text { Window of Opportunity: } \\
\text { larger than } 1 \text { year }\end{array}$ & -0.014 & -1.43 & -0.031 & -1.64 \\
\hline not known & -0.038 & -1.94 & -0.049 & -2.27 \\
\hline log (Age of Product) & -0.054 & -1.89 & Not included & \\
\hline $\begin{array}{l}\text { Share of Best Selling Product: } \\
\text { 30-60\% }\end{array}$ & 0.053 & 1.65 & Not included & \\
\hline $60-80 \%$ & 0.076 & 2.06 & & \\
\hline $80-100 \%$ & 0.116 & 2.23 & & \\
\hline Venture Capital & 0.056 & 0.67 & 0.044 & 0.97 \\
\hline Public Grants & 0.024 & 0.29 & 0.052 & 1.30 \\
\hline International Sales & 0.291 & 2.87 & 0.080 & 1.41 \\
\hline Constant & 1.119 & 10.33 & 0.784 & 12.84 \\
\hline $\begin{array}{l}\text { Summary statistics: } \\
\text { Number of observations } \\
\mathrm{R}^{2}\end{array}$ & \multicolumn{2}{|c|}{503} & \multicolumn{2}{|c|}{$\begin{array}{r}528 \\
0.36\end{array}$} \\
\hline $\begin{array}{l}\text { Specification Tests } \\
\text { Functional Form Reset Test } \\
\text { F }(24,459) / \mathrm{p} \text {-value }\end{array}$ & \multicolumn{2}{|c|}{$1.14 / 0.30$} & \multicolumn{2}{|c|}{$0.60 / 0.92$} \\
\hline $\begin{array}{l}\text { Heteroscedasticity }^{2} \\
\chi^{2} / \mathrm{p} \text {-value }\end{array}$ & \multicolumn{2}{|c|}{$131.15 / 0.00$} & \multicolumn{2}{|c|}{$50.10 / 0.00$} \\
\hline
\end{tabular}

Source: ZEW/LBS (1999)

* based on heteroscedasticity robust standard errors

Notes:

1) Cook-Weisberg test using powers of the fitted values

2) Ramsey Reset test using powers of the exogenous variables 
Table 3: Determinants of Fast Firm Growth - Results using Probit Models

\begin{tabular}{|c|c|c|c|c|c|c|}
\hline \multirow[b]{2}{*}{ Variables } & \multicolumn{2}{|c|}{$\begin{array}{c}\text { Sales and } \\
\text { Employment } \\
\text { Growth }^{2)} \\
25 \% \text { percenters each }\end{array}$} & \multicolumn{2}{|c|}{$\begin{array}{l}\text { Sales Growth } \\
10 \text { percenters }\end{array}$} & \multicolumn{2}{|c|}{$\begin{array}{l}\text { Employment Growth } \\
10 \text { percenters }{ }^{1)}\end{array}$} \\
\hline & Coeff. & t-value & Coeff. & t-value & Coeff. & t-value \\
\hline West-Germany & -0.208 & -1.05 & -0.350 & -1.67 & -0.297 & -1.20 \\
\hline East-Germany & 0.275 & 1.00 & 0.262 & 0.92 & 0.477 & 1.65 \\
\hline ICT-Hardware & 0.296 & 1.28 & 0.049 & 0.19 & 0.428 & 1.57 \\
\hline Engineering & -0.320 & -1.21 & 0.104 & 0.40 & 0.150 & 0.51 \\
\hline Bio/Med/Life & -0.412 & -1.08 & -0.032 & -0.09 & -0.151 & -0.38 \\
\hline Other Industries & -0.210 & -0.86 & -0.578 & -2.13 & -0.080 & -0.29 \\
\hline $\log ($ Age $)$ & -2.088 & -5.48 & -1.844 & -4.70 & -2.789 & -6.18 \\
\hline Log (no. employees at startup) & -0.729 & -5.43 & -0.353 & -2.90 & -1.189 & -6.54 \\
\hline $\begin{array}{l}\text { Number of Founders: } \\
-2-3\end{array}$ & -0.256 & -1.25 & -0.159 & -0.65 & -0.139 & -0.60 \\
\hline$-3-4$ & 0.089 & 0.36 & 0.592 & 2.48 & 0.130 & 0.45 \\
\hline-5 and more & 0.446 & 0.99 & 0.714 & 1.87 & 0.800 & 1.48 \\
\hline Venture Capital & 0.363 & 1.25 & 0.094 & 0.30 & 0.116 & 0.33 \\
\hline Public Grants & 0.292 & 1.38 & 0.302 & 1.31 & 0.293 & 1.16 \\
\hline International Sales & 0.936 & 1.36 & 0.289 & 0.39 & 0.924 & 1.14 \\
\hline Permanent R\&D & -0.066 & -0.40 & 0.591 & 3.15 & 0.070 & 0.36 \\
\hline $\begin{array}{l}\text { Share of Best Selling } \\
\text { Products: } \\
\text { - 30-60\% }\end{array}$ & 0.188 & 0.72 & 0.124 & 0.44 & 0.240 & 0.78 \\
\hline$-60-80 \%$ & 0.087 & 0.32 & 0.434 & 1.50 & 0.067 & 0.21 \\
\hline$-80-100 \%$ & 0.695 & 2.20 & 0.344 & 0.93 & 0.566 & 1.52 \\
\hline Constant & 2.781 & 4.51 & 1.441 & 2.36 & 3.750 & 5.21 \\
\hline Summary statistics: & \multicolumn{2}{|c|}{503} & \multicolumn{2}{|c|}{503} & \multicolumn{2}{|c|}{528} \\
\hline $\begin{array}{l}\text { Number of obs } \\
\text { Wald } \chi^{2}\end{array}$ & \multicolumn{2}{|c|}{84.72} & \multicolumn{2}{|c|}{83.73} & \multicolumn{2}{|c|}{116.24} \\
\hline Pseudo R² & \multicolumn{2}{|c|}{0.24} & \multicolumn{2}{|c|}{0.26} & \multicolumn{2}{|c|}{0.37} \\
\hline
\end{tabular}

Source: ZEW/WBS (1999)

Notes:

1) We define fast growing firms as those firms which belong to the ten percent fastest growing companies. Those firms obtain a value of 1 where all other companies.

2) Firms belonging to the 25 per cent fastest growing enterprises in each dimension of growth. 


\section{References}

Acs, Z.J., \& D.B. Audretsch (1990) "Small Firms and Entrepreneurship: A Comparison between West and East Countries." Discussion Paper FS IV, 90-13, WZ-Berlin.

Agarwal, R. (1998) "Small Firm Survival and Technological Activity." Small Business Economics 11: 215-224.

Aghion, P., \& P. Howitt. (1992) "A Model of Growth Through Creative Destruction.", Econometrica 60(2): 323-351.

Almus, M, E.A. Nerlinger, \& F. Steil. (1999) "Growth Determinants of Start-ups in Eastern Germany: A Comparison Between Innovative and Non-Innovative Firms" In New Technology-Based Firms in the 1990s ed. R. Oakey, \& R.W. During, London (forthcoming).

Bell, J. (1995) "The internationalisation of small computer software firms - A further challenge to stage theories." European Journal of Marketing, 29(8): 60-75.

Bernard, A.B., \& J.B. Jensen. (1999) "Exceptional Export Performance: Cause, Effect, or Both?." Journal of International Economics 47(1): 1-25.

Bernard, A.B., \& J. Wagner. (1997) "Export and Success in German Manufacturing." Weltwirtschaftliches Archiv 133(1): 134-157.

Bloodgood, J.M., H.J. Sapienza, \& J.G. Almeida. (1995) "The Internationalization of New High Potential Ventures: Antecedents and Outcomes." Frontiers of Entrepreneurship, Wellesley, MA: Babson College.

Brüderl, J., P. Preisendoerfer \& R. Ziegler. (1996) Der Erfolg neugegruendeter Betriebe. Duncker \& Humblot: Berlin.

Bürgel, O, A. Fier, G. Licht, G. Murray, \& E.A. Nerlinger. (1998) "The Internationalisation of British and German Start-Up Companies in HighTechnology Industries." ZEW Discussion Paper No. 98-34, Mannheim.

Butchart R. (1987) "A new UK definition of high-technology industries." Economic Trends, 400: 82-88.

Carpenter, R.E., \& B.C. Petersen. (1998) "Is the Growth of Small Firms Constrained by Internal Finance" Emory University and Washington University, Mimeo.

Caves, R.E. (1998) "Industrial Organisation and New Findings on the Turnover and Mobility of Firms." Journal of Economic Literature 34(4): 1947-1982.

Chabral, L. (1995) "Sunk Costs, Firm Size and Firm Growth." Journal of Industrial Economics 43(1): 161-172.

Clerides, S., S. Lach, \& J.R. Tybout. (1998) "Is Learning by Exporting Important? Micro-dynamic Evidence from Colombia, Mexico, and Morocco." Quarterly Journal of Economics 113(4): 903-947.

Cressy, R. (1996) “Are Business Start-ups Debt-rationed?" The Economic Journal 106(4) 1253-1270.

Davis, S.J., J.C. Haltiwanger, \& S. Schuh. (1996) Job Creation and Destruction, Cambrigde, MA: MIT Press.

Dunne, P., \& A. Hughes. (1994) "Age, Size, Growth, and Survival: UK Companies in the 1980s.” Journal of Industrial Economics 42(1): 115-140. 
Ebling, G., \& N. Janz. (1998) "Export Behaviour and Innovation Activities in the Service Sector - Empirical Results for a Cross Section of German Firms", Mimeo, Mannheim.

Eisenhardt, K., \& C. Schoonhoven. (1990) "Organizational Growth: Linking Founding Team, Strategy, Environment, and Growth among US Semiconductor Ventures, 1978-1988." Administrative Science Quarterly 35(3): 504-529.

Ericson, R., \& A. Pakes. (1995) "Markov-Perfect Industry Dynamics: A Framework for Empirical Work." Review of Economic Studies 62(1): 53-82.

Evans, D. S. (1987) "The Relationship between Firm Growth, Size, and Age: Estimates for 100 Manufacturing Industries." Journal of Industrial Economics 35(3): 567583.

Jovanovic, B. (1982) "Selection and Evolution of Industry" Econometrica 50(2): 649670.

Klepper, S. (1996) "Entry, Exit, Growth and Innovation over the Product Life Cycle." American Economic Review 86(2): 560-581.

Lindqvist, M. (1991) Infant Multinationals: The Internationalization of Young, Technology-Based Swedish Firms. Unpublished doctoral dissertation, Stockholm School of Economics, Institute of International Business, Stockholm.

Licht, G., C. Hipp, M. Kukuk, G. Münt, \& N. Janz. (1997), Innovationen im Dienstleistungssektor. Baden-Baden: Nomos.

McDougall, P. P., \& B.M. Oviatt. (1996) "New Venture Internationalisation, Strategic Change and Performance: a Follow-up Study." Journal of Business Venturing 11(1): 23-40.

McDougall, P. P., S. Shane \& B.M. Oviatt. (1994) "Explaining the formation of international new ventures: The limits of international business research" Journal of Business Venturing 9(6): 469-487.

Murray, G.C. (1996) "A Synthesis of Six Exploratory, European Case Studies of Successfully-Exited, Venture Capital Financed, New Technology-based Firms." Entrepreneurship Theory and Practice, 20: 44-60.

Oakey, R., R. Rothwell, \& S. Cooper. (1988) The Management of Innovation in HighTechnology Small Firms, London: Pinter.

Porter, M.E. (1979) "The Structure within Industries and Companies' Performance." Review of Economics and Statistics 61(1): 214-227.

Reuber, A.R., \& E. Fisher. (1997) "The influence of the management team's international experience on the internationalization behaviour of SMEs." Journal of International Business Studies 28: 807-825.

Roberts, M. J., \& J. R. Tybout (1997) "The Decision to Export in Colombia: An Empirical Model of Entry with Sunk Costs" American Economic Review 87(2): 545-564.

Storey, D. J. (1994) Understanding the Small Business Sector, London.

Sutton, J. (1997) “Gibrat's Legacy.” Journal of Economic Literature 35(1): 40-59.

Wagner, J. (1992) "Firm Size, Firm Growth, and Persistence of Chance: Testing Gibrat's Law with Establishment Data from Lower Saxony, 1978-1989." Journal of Small Business Economics 4(1): 125-131. 
Wakelin, K. (1998) "Innovation and Export Behaviour at the Firm Level." Research Policy 26(4): 829-841. 